\title{
The Development of Fabel $E$-Comic in Bahasa Indonesia Lesson for Grade II of Elementary School
}

\author{
Anak Agung Istri Dwiasih ${ }^{1 *}$, Anak Agung Gede Agung ${ }^{1}$ \\ ${ }^{1}$ Universitas Pendidikan Ganesha, Indonesia \\ *Corresponding author. Email: gungiss076@gmail.com
}

\begin{abstract}
The Development of Fabel E-Comic in Bahasa Indonesia Lesson for Grade II Of Elementary School. During online learning process in the era of covid-19, there is the lack of students understanding in reading learning process especially in looking for information from the text of fable and the lack of instructional media application from the teacher during learning process in Bahasa Indonesia class. It causes the students are not interested to the materials. Therefore, an instructional media that can make the students are interested in the learning process is needed so that the learning process can be interesting for the students. The aim of this research is to describe the development process and to find out the validation result of Fable E-Comic based on the review of the experts, individual try out, and small group try out. This research used development research which applied ADDIE. The data were collected using questionnaire and were analysed using descriptive quantitative method. The result from the analysis were the result from the subject master got 100 with very good qualification, the result from the instructional design expert got 91.42 with very good qualification, the result from the instructional media expert got 89.41 with good qualification, the result from the individual try out on 3 students got 93.33 with very good qualification, and the result from small group try out on 9 students got 94.66 with very good qualification. Based on the result of the product try out from the experts (subject master, instructional design expert, and instructional media expert) and the result of the try out on the subject of the research (students), it can be concluded that Fable E-comic can be used to teach Bahasa Indonesia for the second grade students of elementary school.
\end{abstract}

Keywords: ADDIE, e-comic, development

\section{INTRODUCTION}

Education is one of the needs to improve and to explore one self's potential. Education is aimeed to develop students' potential to be faithful, feat to the one and only God, have a noble character, healthy, wellknowledged, creative, independent, and become democrative and responsible [1]. The effort that can be done to reach this goal is through learning process. In learning process, there is an interaction between the teacher, students, and other learning components. The accomplishment of the learning objectives is one of the factors that defines the success of teaching and learning process [2]. The learning activity that is done by the teachers should establish and develop creative and innovative learning, especially when the learning process have to be done remotely. It makes the education turns upside down because it has to change to be done online during the global pandemic of covid-19. Therefore, a creative idea from the teacher is needed to change the situation to be interesting and effective and to make the students become active in class. According to [3] teachers' creativity is the ability of a teacher to create something new or to combine previous ideas that can be useful and easy to be understood. Therefore, teacher can apply innovative learning in technological education.

Technological education is a system that can be used to support the learning process so it can reach the expected result [4]. This opinion is similar to [5] who stated that technological education is an effort to solve the problems related to learning process. Moreover, [6] stated that technological education is a field of applied science that integrates sinergically some disciplines to simplify the learning process, increase the quality of learning, and increase the performance quality. It can be concluded that technological education is a way that can be used to support the learning process. Technology can help learning process since it development has improved education, especially in learning process. It is similar to [7] which stated technological education is aimed to solve the problems in learning process and it is expected 
to give many benefits in improving the quality and the effectivity in learning process.

Therefore, learning process needs to be planned so it can be done effectively and efficiently by applying technological education as the instructional media used by the teaching in supporting the learning process. But in fact, what happened in the classroom is not as what as expected. Based on the data from the interview in SD No. 2 Mengwi, Mengwi, Badung, there are some students who got low score because of the online learning process in this global pandemic situation. It also caused by students' lack of understanding in reading the materials. There is also a problem in the second grade of SDN 2 Mengwi which is the lack of insctructional media application during learning process. The only instructional media that was used is just the images from the book given by the school, especially in Bahasa Indonesia class for second grade of elementary school about exploring information from the folklore. Folklore is a folk prose that never happened in real life. The aimed of this prose is just for entertainment, even though there are many folklores that describes reality and have moral value in it [8]. Bahasa Indonesia learning about exploring information from a folklore is still considered hard for the students because the teacher only use the text from the teaching book. It makes the students are not interested in the learning process. For that reason, interesting instructional media is needed to make the learning process enjoyable and more interesting for the students.

As an effort to help the students increasing their reading interests and motivates them to learn during the online learning process, a flexible instructional media is developed so the students can learn it independently from home. SDN 2 Mengwi has adequate facilities in online learning process. Both teachers and students already have supportive gadgets such as laptop, computer and handphone for learning activity. Because of this, Fable EComic that can support learning process in exploring information from fable in Bahasa Indonesia can be developed.

Instructional media is anything that can be used to deliver sender's messages to the recipients, that it can stimulate thoughts, feelings, attentions, and students' interest in learning [9]. Moreover, [10] stated that instructional media is anything that can be used to stimulate thoughts, feelings, attentions, and students' ability so that it can push the learning process to be happened. This statement is also similar to [11] which stated instructional media is a tool that is used to deliver information which has certain instructional objectives to the recepients so it can motivate students to learn. From those statements, it can be concluded that instructional media is a tool that can be used to deliver messages or informations in learning process which delivered with instructional material. Instructional media is also able to raise students' motivation and interest in increasing the understanding of the learning. Students who are learning with instructional media tends to be more attracted to learn compared to other students who only listen to the teachers' explanation [12]. Therefore, there must be the instructional media which suits the material that will be taught so it can increase students' motivation and interest in learning process.

In the implementation of education, government has done many efforts to get the optimal result including the revision of curriculum. Currently, curriculum 2013 is applied. This curriculum is not teacher-centered anymore, but it is more focusing on the students' activity. Curriculum 2013 is also known as a character-based curriculum which has special characters of integrative learning. Integrative learning is designed using special themes and it is reviewed from several lessons. In integrative learning, students are not learning lessons like Bahasa Indonesia, science, social, mathematics, or any other lessons anymore, but they are studying the theme which already includes all lessons and its competencies. From this integrative learning, elementary school students can learn easier and get meaningful experience, improve their learning results, and got their characters developed in elementary school [13].

One of the competencies that needs to be developed is Bahasa Indonesia competency. Bahasa Indonesia is one of the lessons that should be taught in elementary school since it is the tool of communication and also one of the unique characteristics of Indonesia that is used as a national language. These are the reasons of having Bahasa Indonesia in every educational level especially in elementary school because it is the basic of all lessons [14]. Bahasa Indonesia has important level and function in daily life. The implementation of Bahasa Indonesia from early age is by giving exercise and education of Bahasa Indonesia. The teaching of Bahasa Indonesia is to exercise the ability of listening, speaking, reading, and writing.

This research is supported by previous researches. Irawati \& Lisa. R., [15] in their research stated that Ecomic is suitable to be used as instructional media that can help teacher during learning process. It is proven by the result from the material expert which was $98 \%$, media expert $95 \%$, and from students' questionnaire $97 \%$. Purnamasari et al., [16] in their research also stated that E-comic has fulfilled the criteria so it can be used as an instructional media. Moreover, Aeni \& Yusupa, [17] in their research prove that the development of E-comic have become the answer for the needs of innovative, interesting, effective and efficient instructional media and it can improve students' attention in understanding the materials. Wicaksana et al., [7] stated that E-comic gave positive impact to students' learning motivation. Angga et al., [18] also stated that E-comic which focuses on the character education is good to be applied and it is expected to improve students' motivation in learning so 
that it can improve the learning result of the students. Kustianingsari \& Dewi, [19] in their research stated that there were significant effect of the use of e-comic towards the improvement of the elementary school students. Sukmanasa, [20] in their research stated that ecomic can be developed and suitable to be used in the elementary school students' learning process. Prihanto \& Yunianta, [21] in their research stated that e-comic is valid, effective, and practical to be used in learning fractional material in the fifth grade of elementary school. Noer \& Abrori, [22] stated that comic instructional media is valid to be used in learning based on the validation of the experts, teachers, and students. Zuhrowati et al., [23] stated that comic media that developed interestingly, easy to use, and impactful is proven to be effective to be used as instructional media. Anesia et al., [24] in their research stated that Android based comic media that was developed is suitable to be used in learning process. Lubis, [25] stated that the comic that was developed is effective in increasing students' reading interest, specifically in PPKn lesson with joint decision material for the fifth grade students. Based on those research, it can be concluded that e-comic can be used as the instructional media in teaching and learning process.

E-comic itself has its own convenience in terms of the usage. On the other side, comic can be used for the independent learning for the students so it can motivate them to learn. It is similar to a statement stated by [18] they stated that comic based instructional media can improve interest, motivation, understanding, and characters so the learning result of the students are improved. Another statement from [26] who stated that comic is interesting for the children because it is fun and easy to read and it can stimulate children's imagination. Moreover, according to [27] comic is a media that can attract people from all ages especially children because it is interesting and easy to be understood and it is suitable for the elementary school students who likes stories and colorful images.

E-comic with fable is expected to increase students interest in reading because the plot of the story is served to be easy to understand for the elementary school students and it has positive characteristics and moral value includes in the dialogue and in the characters that served educatively. Based on that background, this research is aimed to describe the process of the development of fable E-comic and to find out the validation result of fable E-comic in Bahasa Indonesia lesson for the second grade of elementary school based on the review from the experts and user try out from individuals and small groups.

\section{METHOD}

Research design used in this research is research and development with the product of fable E-comic instructional media. In this research, E-comic instructional media is developed using ADDIE development model. ADDIE model has 5 stages that needs to be done systemically and systematically. There are analyze, design, development, implementation, and evaluation in which the application is easy to be understood and to be implemented in the development process of research product [28]. The chosen of this model is based on the consideration of this model is developed sistematically and based on the theoretical base of instructional design. Moreover, ADDIE model is arranged programmatically with systematical activity order to solve the learning problems that connected to the source of learning which suitable for the needs and the characteristics of the learners.

This research used questionnaire to collect the data. Questionnaire is a way to get or to collect the data by sending a list of questions to the respondents or the subject of the research [29]. Questionnaire method is used in product try out on the subject which are the material expert, instructional design expert, instructional media expert, individual try out, and small groups try out on the students. The instrument of collecting the data in this research is questionnaire.

The instrument blue print for the material expert, instructional design expert, instructional media expert, individual try out, and small groups test are on the table $1,2,3$, and 4 .

Table 1. Instrument Blue Print for Material Expert

\begin{tabular}{|l|l|c|}
\hline \multicolumn{1}{|c|}{ Aspect } & \multicolumn{1}{c|}{ Indicator } & Number \\
\hline \multirow{2}{*}{ 1. Material } & $\begin{array}{l}\text { a. The compatibility of the material with core competency, indicator, } \\
\text { and instructional objectives. }\end{array}$ & $1,2,3$ \\
\cline { 2 - 4 } & b. The compatibilty of the materials & 4,5 \\
\hline 2. Language & a. Easy to be understood & 6,7 \\
\hline 3. Evaluation & a. Test quality & $\mathbf{2}$ \\
\cline { 2 - 4 } & b. The balance of test proportion with the materials & 9,10 \\
\hline \multicolumn{1}{|c|}{ Total } & $\mathbf{1 0}$ \\
\hline
\end{tabular}

(Source: [30]) 
Table 2. Instrument Blue Print for Instructional Design Expert

\begin{tabular}{|l|l|c|c|}
\hline \multicolumn{1}{|c|}{ Aspect } & \multicolumn{1}{|c|}{ Indicator } & Number & Total \\
\hline 1. Objective & a. The clarity of instructional objective & 1 & 1 \\
\hline \multirow{3}{*}{ 2. Strategy } & $\begin{array}{l}\text { a. The compatibility of delivering strategy with the students } \\
\text { characteristics }\end{array}$ & 2 & 1 \\
\cline { 2 - 4 } & b. The accuracy of delivering strategy & 3 & 1 \\
\cline { 2 - 4 } & c. The presentation of the material is able to motivate the students & 4,5 & 2 \\
\hline \multirow{2}{*}{ 3. Evaluation } & a. The clarity of the test instruction & 6 & 1 \\
\cline { 2 - 4 } & b. The quality of the test & 7 & 1 \\
\hline
\end{tabular}

(Source: [30])

Table 3. Instrument Blue Print for Instructional Media Expert

\begin{tabular}{|c|c|c|c|}
\hline Aspect & Indicator & Number & Total \\
\hline \multirow{4}{*}{ 1. Interface } & a. Interface design & 1,2 & 2 \\
\hline & b. Text & $3,4,5,6$ & 4 \\
\hline & c. Image & $7,8,9,10$ & 4 \\
\hline & d. Color & 11,12 & 2 \\
\hline \multirow[t]{2}{*}{ 2. Technical } & a. The convenience of media usage & 13 & $\overline{1}$ \\
\hline & b. The usage of the media can increase students' motivation & 14 & 1 \\
\hline \multirow{2}{*}{$\begin{array}{l}\text { 3. Accuracy, } \\
\text { Novelty, and } \\
\text { Clarity }\end{array}$} & a. The accuracy of the materials in the media & 15 & 1 \\
\hline & b. The novelty of the media & 16,17 & 2 \\
\hline \multicolumn{3}{|c|}{ Total } & 17 \\
\hline
\end{tabular}

(Source: [30])

Table 4. Instrument Blue Print for Individual and Small Group Try Out

\begin{tabular}{|c|c|c|c|}
\hline Aspect & Indicator & Number & Total \\
\hline \multirow[t]{4}{*}{ 1. Interface } & a. Interface design & 1,2 & 2 \\
\hline & b. Text & 3 & 1 \\
\hline & c. Image & 4,5 & 2 \\
\hline & d. Color & 6 & 1 \\
\hline \multirow[t]{2}{*}{ 2. Materials } & a. Content & 7 & 1 \\
\hline & b. Easy to be understood & 8 & 1 \\
\hline \multirow[t]{2}{*}{ 3. Technical } & a. The convenience of using the media & 9 & 1 \\
\hline & b. The usage of the media can increase students' motivation & 10 & 1 \\
\hline 4. Evaluation & a. The clarity of the test instruction & 11 & 1 \\
\hline \multicolumn{3}{|c|}{ Total } & 11 \\
\hline
\end{tabular}

(Source: [30])

Data analysis method that was used in this development research was descriptive quantitative analysis method. This method was used to analyse the data from the material expert, instructional design expert, instructional media expert, and individual and small groups try out. In making decision of E-comic media qualification, the attainment rate conversion with 5 scales is used and can be seen from the Table 5 below.

Table 5. The Attainment Rate Conversion with 5 Scales

\begin{tabular}{|c|c|c|}
\hline $\begin{array}{c}\text { Achievement } \\
\text { Level (\%) }\end{array}$ & Category & Details \\
\hline $90-100$ & Very Good & $\begin{array}{c}\text { No need } \\
\text { revision }\end{array}$ \\
\hline $75-89$ & Good & $\begin{array}{c}\text { Revise as } \\
\text { necessary }\end{array}$ \\
\hline $65-79$ & Enough & $\begin{array}{c}\text { Pretty much } \\
\text { revision }\end{array}$ \\
\hline $55-64$ & Bad & Many revisions \\
\hline $0-54$ & Very Bad & Total revision \\
\hline
\end{tabular}

(Source: [31])

\section{RESULT AND DISCUSSION}

\subsection{Result}

In this development research, the product that was produced was fable E-comic media. Comic is a visual communication media that has the power to deliver information in a popular way and easy to be understood [15]. This media is developed to facilitate the second grade students of elementary school so they can improve their reading interest to explore the information from the fable they read. The developed media consists fable which is the materials from Bahasa Indonesia lesson. Fable E-comic media includes supporting images which was relevant to fable, so it can make the students easier to get the meaning and the moral value when they read the story.

The determination of the materials was done by taking concern of the current curriculum, curriculum 2013 and the integrated thematic book which are 
teacher's handbook and students' handbook so it can get one theme that is suitable to be included in fable E-comic media. The theme that was chosen was Theme 7 Togetherness with the materials of exploring information from fable. This material was included in Bahasa Indonesia lesson for the second grade of elementary school as in curriculum 2013.

Table 6. Validity Result of Fable E-comic Development
Fable E-comic media was tested using validity test that aimed to test the eligibility level of E-comic media with ADDIE model. The developing instrument of this E-comic is the questionnaire that aimed to find out the validity of the product. Further details of the result of fable E-comic validity based on the test on material expert, instructional design expert, instructional media expert, and individual and small group try out can be seen from Table 6 below.

\begin{tabular}{|c|c|c|c|}
\hline No & Try Out Subject & Validity Result (\%) & Details \\
\hline 1. & Material Expert & 100.00 & Very Good \\
\hline 2. & Instructional Design Expert & 91.42 & Very Good \\
\hline 3. & Instructional Media Expert & 89.41 & Good \\
\hline 4. & Individual Try Out & 93.33 & Very Good \\
\hline 5. & Small Group Try Out & 94.66 & Very Good \\
\hline
\end{tabular}

Based on the result from material expert test, the result then converted with convertion 5 scale achievement level table. The percentage of achievement level from the material expert is 100 and it is on the Very Good qualification. According to the analysis of the notes, suggestion, and comment, the material expert did not give any revision suggestion. The revision was not given because the fable E-comic got Very Good qualification, so it can be a consideration to not doing any revision.

Based on the result from instructional design expert test, the result then converted with convertion 5 scale achievement level table. The percentage of achievement level from the material expert is 91.42 and it is on the Very Good qualification. According to the analysis of the notes, suggestion, and comments from the expert, there are some revision on the instructional indicator and instructional objective. Those suggestions then become the references to make this fable E-comic better.

Based on the result from instructional media expert test, the result then converted with convertion 5 scale achievement level table. The percentage of achievement level from the material expert is 89.41 and it is on the Good qualification. According to the analysis of the notes, suggestion, and comments from the expert, there are some revisions for the background of the E-comic, color, and dialogue text size in E-comic. Those suggestions then become the references to make this fable E-comic better.

Based on the result from individual try out, the result then converted with convertion 5 scale achievement level table. The percentage of achievement level from the material expert is 93.33 and it is on the Very Good qualification. And from the small groups try out, the result also converted with convertion 5 scale achievement level table and it got 94.66 with Very Good qualification.

From those results, it can be concluded that fable Ecomic is suitable to be applied but still need some revision according to the insights, comments, and suggestions given by the instructional design expert and instructional media expert. Further details of fable Ecomic revision can be seen from table 7 and 8 below.

Table 7. Instructional Design Expert Product Revision

\begin{tabular}{|c|l|l|}
\hline No. & \multicolumn{1}{|c|}{$\begin{array}{c}\text { Insights, } \\
\text { Suggestions, and } \\
\text { Comments }\end{array}$} & \multicolumn{1}{|c|}{ Revision } \\
\hline 1. & $\begin{array}{l}\text { The instructional } \\
\text { indicator should use } \\
\text { HOTS (Higher Order } \\
\text { Thinking Skill) so it } \\
\text { can suits K13 } \\
\text { learning. }\end{array}$ & $\begin{array}{l}\text { To revise the } \\
\text { instructional indicator } \\
\text { to HOTS (Higher } \\
\text { Order Thinking Skill) } \\
\text { as in K13. }\end{array}$ \\
\hline 2. & $\begin{array}{l}\text { Match the instructional } \\
\text { objective with the } \\
\text { instructional indicator }\end{array}$ & $\begin{array}{l}\text { To match the } \\
\text { instructional objective } \\
\text { with the instructional } \\
\text { indicator }\end{array}$ \\
\hline
\end{tabular}

Table 8. Instructional Media Expert Product Revision

\begin{tabular}{|l|l|l|}
\hline No. & \multicolumn{1}{|c|}{$\begin{array}{c}\text { Insights, } \\
\text { Suggestions, and } \\
\text { Comments }\end{array}$} & \multicolumn{1}{c|}{ Revision } \\
\hline 1. & $\begin{array}{l}\text { Make the background } \\
\text { relate to elementary } \\
\text { school students' reality }\end{array}$ & $\begin{array}{l}\text { To change the } \\
\text { background so it can } \\
\text { relate the reality of } \\
\text { elementary school } \\
\text { students }\end{array}$ \\
\hline 2. & $\begin{array}{l}\text { Brightening the color of } \\
\text { the E-comic }\end{array}$ & $\begin{array}{l}\text { To change the color of } \\
\text { the E-comic so it will } \\
\text { become brighter }\end{array}$ \\
\hline 3. & $\begin{array}{l}\text { Adjust the dialogue } \\
\text { text size of the E-comic } \\
\text { so the students can } \\
\text { read it clearly }\end{array}$ & $\begin{array}{l}\text { To adjust the dialogue } \\
\text { text size of the E- } \\
\text { comic so the students } \\
\text { can read it clearly }\end{array}$ \\
\hline
\end{tabular}

The result of the fable E-comic development can be seen from figure 1 and 2 below. 


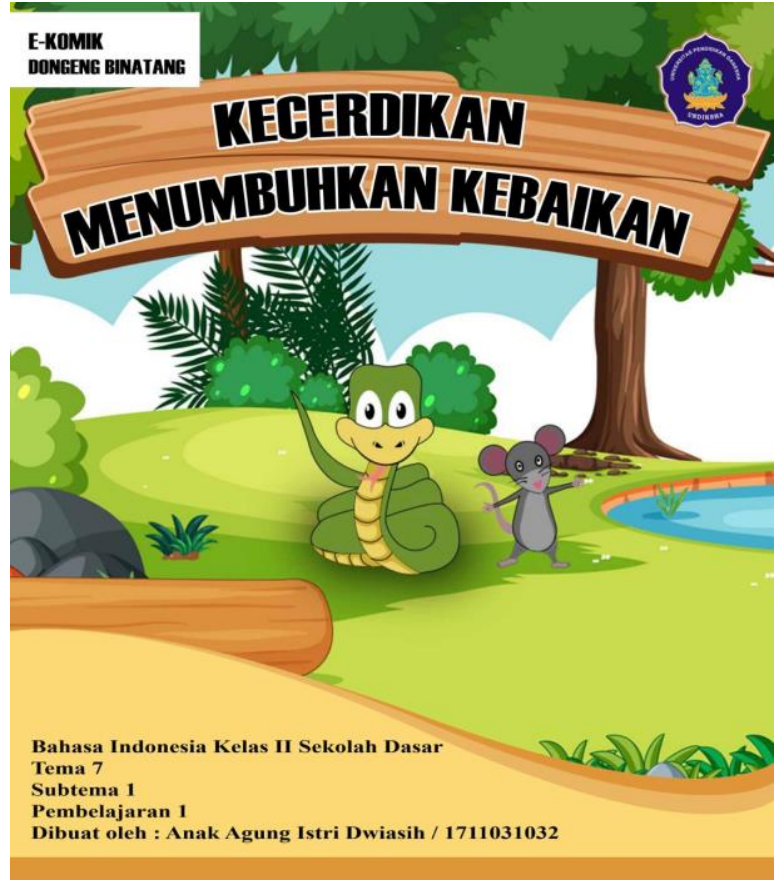

Figure 1. Fable E-Comic Cover
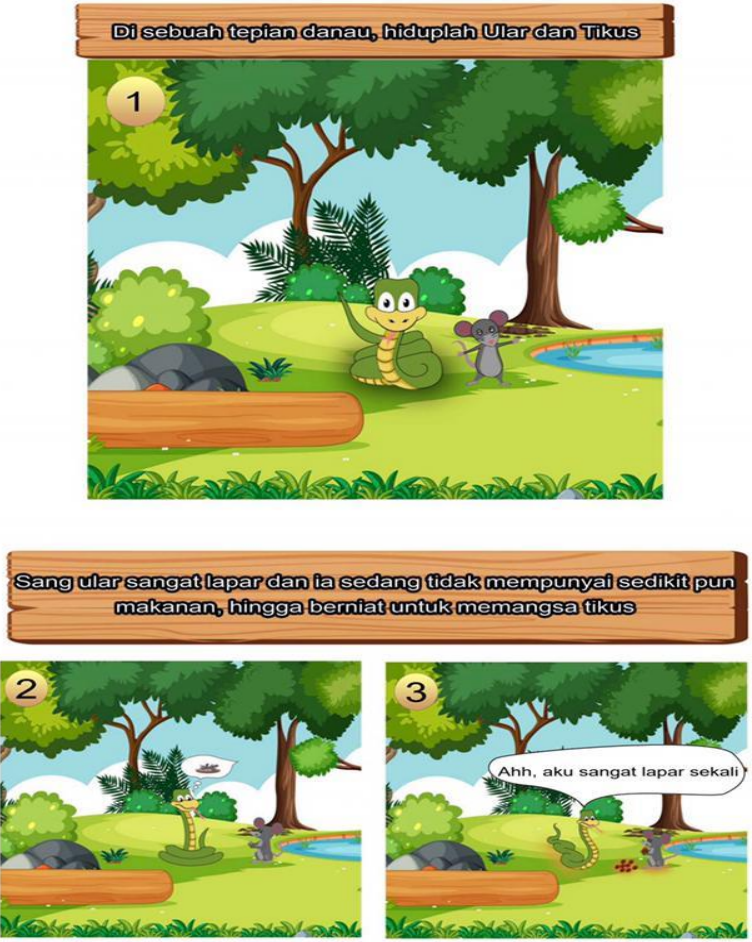
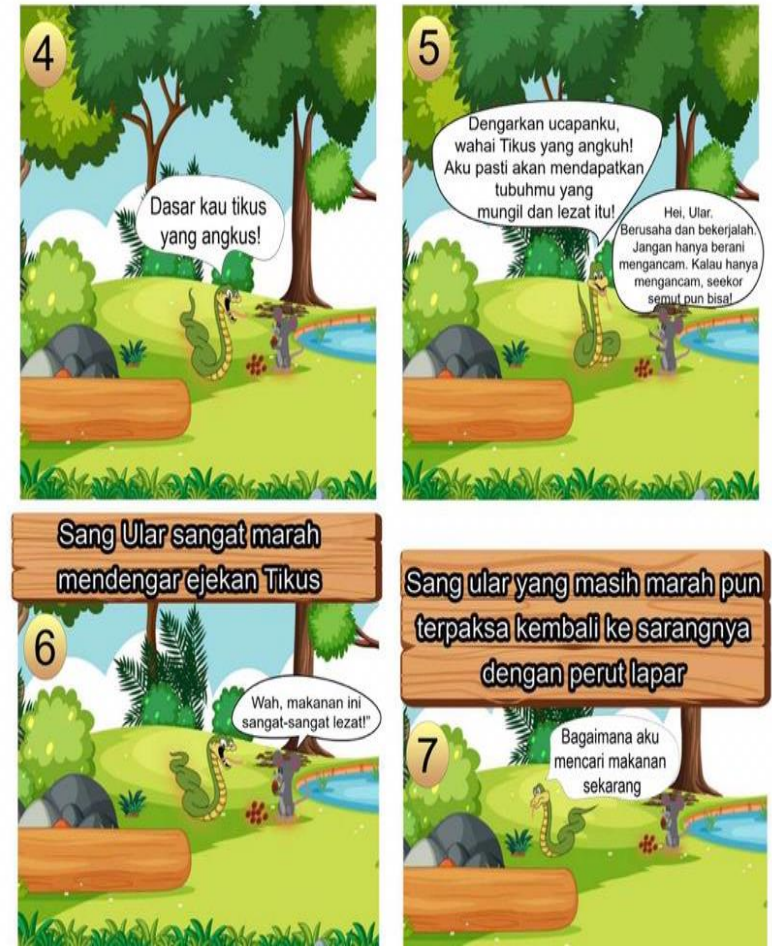

Figure 2. Content of Fable E-Comic

\subsection{Discussion}

The development of this fable E-comic used ADDIE model which consist of 5 stages. There are analysis, design, development, implementation, and evaluation. This research was taking place at SDN 2 Mengwi. Below is the discussion of this development research.

First, the researcher did the analysis stage. In this stage it was known that there were some of the second grade students of SDN 2 Mengwi got low result on the online learning process. It was caused by the lack of students' understanding especially in reading the materials. The problem happened in the second grade of SDN 2 Mengwi is the lack of instructional media application in teaching and learning process. The only instructional media used by the teacher was just thematic handbooks which are teacher handbook and students handbook so it make the students are bored during learning process. Therefore, an interesting media was needed to make the learning process become more effective, especially in Bahasa Indonesia lesson about exploring information from the fable that usually delivered with just a text. Fable E-comic media that was used to support the learning process was expected to increase students reading interest so they can explore the information of the fable that was delivered in the form of E-comic. The usage of interesting instructional media is a way to increase students understanding of the materials [32].

The second stage that was done was designing stage. In this stage, the information that was gotten from the 
analysis stage was transformed into document form that will be the aim of the instructional media development. The steps that need to be done in this stage are deciding the software that will be used, which were Adobe Photoshop with the end product in Portable Document Format (PDF) file. After that, the characters that will be used in the fable E-comic and other supporting images are sketched. It is to sketch the concept roughly and to make the characters' expression looks real. After that the next step was designing the storyboard and the fable ecomic media design. Designing the storyboard is to specify the plot, images, and dialogues in E-comic from the beginning until the end of the story. The instructional media was designed as interesting as it could be to attract students attention and their reading interest, just like designing the fable E-comic using images and presenting the fable which includes moral value. Moreover, the use of color is also become the focus of the development of this media.

The third stage was developing stage. In this stage, the product was developed based on the design. In this stage, fable E-comic was developed with the moral value included. The chosen fable was suited with the story in the thematic handbook. Fable E-comic was consist of the cover, content, and some practices that related to the story. In the developing process of fable E-comic media, the eligibility needs to be known before it is used and applied in the learning process. The product eligibility was validated by the experts and by the students through individual and small group try out. The product eligibility test involved material expert, instructional design expert, and instructional media expert.

The fourth stage was implementing stage. In this stage, the product supposed to be applied in the learning process. But since this research was done in the middle of the global pandemic, it is impossible to apply this product directly in the classroom. Therefore, the implementation stage could not be done in this research.

The last stage was evaluation stage. Evaluation that was done in this research was formative evaluation. Formative evaluation was done to measure the instructional media product that includes the validation from the material expert, instructional design expert, instructional media expert, and individual and small group try out.

According to the material expert's review, it was known that fable E-comic got 100 percentage of achievement level and it was on the Very Good qualification. The objective and the delivered materials were compatible with the instructional objective and curriculum 2013. The design of fable E-comic got very good qualification because the presentation of the material is suitable with the core competency, basic competency, and the lesson plan that were used. In developing an instructional media, the compatibility of the material in the instructional media must suit the instructional objective. From the review of the material expert, it can be concluded that the developed fable Ecomic is valid and can be used for the students in their learning process, especially in Bahasa Indonesia lesson.

According to the instructional design experts, it was known that fable E-comic got 91.42 percentage and it was on the Very Good qualification. The instructional design was developed so it can support the learning process. The instructional design was made based on the expected result and the possible process that will be applied on the students so the learning process will become more effective [33]. The design of fable E-comic instructional media got very good qualification because the media was able to motivate the students during the learning process and it can make the learning process more interesting. From the review of the instructional design expert, it can be concluded that the developed fable E-comic instructional media is valid and can be used for the students in their learning process, especially in Bahasa Indonesia lesson.

According to the instructional media experts, It was known that fable E-comic got 89.41 percentage and it was on Good qualification. From the interface, fable Ecomic consists colorful images from the fable, characters' dialogue, and moral value so it can attract students' attention to learn with fable E-comic media. According to [34] communication process is a process of delivering message from one source through certain media to the recipients. From this statement, it can be concluded that a media can be used to deliver a message to the recipient. It is similar to the reason of developing fable E-comic media with the aim of the students can explore information and find out the moral value from the fable they read. From the review of the instructional media expert, the developed fable E-comic is compatible with the students' characteristic. It can be concluded that fable E-comic has good role and suitable to be used in the learning process especially for Bahasa Indonesia lesson.

After reviewed by the experts, fable E-comic media was tested on the students. The try out was consist of individual try out and small group try out. From the individual try out, fable E-comic media got 93.33 percentage with Very Good qualification and the validation from the small group got 94.66 percentage with Very Good qualification. Fable E-comic got very good qualification because there are some interesting stuff in the media, there re the presentation of fable in the form of E-comic which includes the moral value of the story and colorful interesting images that attract students interest in reading the fable E-comic to find out the information of a fable text.

This fable E-comic was presented in the form of electronic comic which is the images of the fable with dialogues of the characters. Images can help to reach the goal of understanding and remembering the information or the message involved in the story. Interesting images 
in E-comic media was also influence the interest to raise students' motivation in studying. It is also similar to the statement from [34] who stated that colored images is more recommended to be used in instructional media than black and white images. Colored images can give the fact or real impression of the presented object and it also can give real understanding and attract students' attention.

Based on the review with very good qualification, the developed fable E-comic got very good response from the try out on the students. From the insights, comments, and suggestions on the try out, there was nothing to be revised. The fable E-comic that was developed can make the students easier to understand the material from exploring the information of a fable. Moreover, fable Ecomic also can attract students interest in learning so that the students can be motivated in learning and it also can increase their learning result as well as their reading interest.

\section{CONCLUSION}

In the learning process that is held online in times of global pandemic, there is the lack of students understanding in learning, especially in reading, to be spesific in Bahasa Indonesia lesson with the material of exploring information from fable text and the lack of the application of instructional media by the teacher in teaching and learning process that caused the students easily get bored while studying. Therefore, an instructional media that can attract students' learning and reading interest is needed to make the learning process become more interesting and more fun for the students and fable E-comic was the answer. This research is a development research with ADDIE model. Based on the research from some experts and from the individual and small group test, it can be concluded that fable E-comic on Bahasa Indonesia lesson is good to be used as the instructional media. It is based on the result of the test that has been done in which from the material expert this product got 100 with Very Good qualification, from instructional design expert got 91.42 with Very Good qualification, from instructional media got 89.41 with Good qualification, from individual test got 93.33 with Very Good qualification, and from small test got 94.66 with Very Good qualification.

The suggestion that can be given are first, there must be a further development from this fable E-comic which this comic was used as a supportive media that was developed by the developer itself. Second, on the next research there must be effectivity test to find out the effectivity level of this product in increasing learning result and students' reading interest in Bahasa Indonesia lesson.

\section{REFERENCES}

[1] I. W. C. Sujana, Fungsi Dan Tujuan Pendidikan Indonesia, Adi Widya: Jurnal Pendidikan Dasar 4(1) (2019) 29.

DOI: https://doi.org/10.25078/aw.v4i1.927

[2] A. Emda, Kedudukan Motivasi Belajar Siswa Dalam Pembelajaran, Lantanida Journal 5(2) (2018) 172 DOI: https://doi.org/10.22373/lj.v5i2.2838

[3] Abdullah, R. (2017). Pembelajaran Dalam Perspektif Kreativitas Guru Dalam Pemanfaatan Media Pembelajaran. Lantanida Journal, 4(1), 35. https://doi.org/10.22373/lj.v4i1.1866

[4] S. Lestari, Peran Teknologi dalam Pendidikan di Era Globalisasi, Edureligia; Jurnal Pendidikan Agama Islam 2(2), (2018) 94-100. DOI: https://doi.org/10.33650/edureligia.v2i2.459

[5] U, Hanifah Salsabila, L, Irna Sari, K. Haibati Lathif, A. Puji Lestari, A. Ayuning, Peran Teknologi Dalam Pembelajaran Di Masa Pandemi Covid-19, AlMutharahah: Jurnal Penelitian Dan Kajian Sosial Keagamaan 17(2) (2020) 188-198. DOI: https://doi.org/10.46781/al-mutharahah.v17i2.138

[6] D. Surani, Studi Literatur: Peran Teknologi Pendidikan dalam Pendidikan 4.0, Prosiding Seminar Nasional Pendidikan FKIP 2(1) (2019) 456-469.

[7] I. P. G. C. R. Wicaksana, A. A. G. Agung, I. N. Jampel, Pengembangan E-Komik Dengan Model Addie Untuk Meningkatkan Minat Belajar Tentang Perjuangan Persiapan Kemerdekaan, Jurnal Edutech 7(2) (2020) 48-59. DOI: https://ejournal.undiksha.ac.id/index.php/JEU/articl e/view/23159

[8] R. Rukiyah, Dongeng, Mendongeng, dan Manfaatnya, Anuva 2(1) (2018) 99. DOI: https://doi.org/10.14710/anuva.2.1.99-106

[9] T. Tafonao, Peranan Media Pembelajaran Dalam Meningkatkan Minat Belajar Mahasiswa, Jurnal Komunikasi Pendidikan 2(2) (2018) 103. DOI: https://doi.org/10.32585/jkp.v2i2.113

[10] P. Ekayani, Pentingnya Penggunaan Media, March, 2017.

https://www.researchgate.net/publication/3151056 51

[11] P. Rumput, S. D. N. Pengadilan, Pengembangan Media Pembelajaran Komik Digital Pada Kelas V Sekolah Dasar di Kota Bogor Elly Sukmanasa, Tustiyana Windiyani, Lina Novita Pendidikan Guru Sekolah Dasar Universitas Pakuan A, Pendahuluan 
Penyampaian informasi terjadi dalam proses pembelajan 3(2) (2017) 171-185.

[12] R. M. Putri, E. Risdianto, N. Rohadi, Pengembangan Media Pembelajaran Interaktif Dengan Menggunakan Adobe Captivate Pada Materi Gerak Harmonik Sederhana, Jurnal Kumparan Fisika 2(2) (2019) 113-120. DOI: https://doi.org/10.33369/jkf.2.2.113-120

[13] D. G. A. P. Prabawa, M. P. Restami, Pengembangan Multimedia Tematik Berpendekatan Saintifik untuk Siswa Sekolah Dasar, Mimbar PGSD Undikhsa 8(3) (2020) 479-491.

[14] O. Farhrohman, Implementasi Pembelajaran Bahasa Indonesia di SD / MI, Jurnal Primary 09(1) (2017) 24.

[15] Irawati, R. Lisa, Pengembangan E-Comic Sebagai Media Pembelajaran Ekonomi Kelas X di SMAN 7 Malang Pokok Bahasan Sistem Pembayaran dan Alat Pembayaran, Vol. 09, 2016. http://journal2.um.ac.id/index.php/jpe/article/view/ 1620

[16] H. Purnamasari, S. Siswoyo, V. Serevina, Pengembangan Media Pembelajaran E-Komik Pada Materi Dinamika Rotasi, VII, SNF2018-PE-29SNF2018-PE-35, 2018. DOI: https://doi.org/10.21009/03.snf2018.01.pe.05

[17] W. A. Aeni, A. Yusupa, Model Media Pembelajaran E-Komik Untuk SMA, Jurnal Kwangsan 6(1) (2018) $1 . \quad$ DOI: https://doi.org/10.31800/jurnalkwangsan.v6i1.66

[18] P. M. W. Angga, I. K. Sudarma, I. K. Suartama, EKomik Pendidikan Untuk Membentuk Karakter Dan Meningkatkan Hasil Belajar Siswa Kelas V Pada Mata Pelajaran Bahasa Indonesia, Jurnal Edutech Undiksha 8(2) (2020) 93. DOI: https://doi.org/10.23887/jeu.v8i2.28920

[19] N. Kustianingsari, U. Dewi, Pengembangan Media Komik Digital Pada Mata Pelajaran Bahasa Indonesia Tema Lingkungan Sahabat Kita Materi Teks Cerita Manusia dan Lingkungan Untuk Siswa Kelas V SDN Putat Jaya III/379 Surabaya, Jurnal Mahasiswa Teknologi Pendidikan 6(2) (2015) 1-9.

[20] E. Sukmanasa, T. Windiyani, L. Novita, Pengembangan Media Pembelajaran Komik Digital Pada Mata Pelajaran Ilmu Pengetahuan Sosial Bagi Siswa Kelas V Sekolah Dasar di Kota Bogor, JPsd (Jurnal Pendidikan Sekolah Dasar) 3(2) (2017) 171185.

[21] D. Prihanto, T. N. Yunianta, Pengembangan Media Komik Matematika pada Materi Pecahan Untuk
Siswa Kelas V Sekolah Dasar, Maju 5(1) (2018) 7990.

[22] R. Z. Noer, F. M. Abrori, Pengembangan Komik Pembelajaran pada Materi Bumi dan Alam Semesta untuk Siswa Sekolah Dasar Kelas VI di SDN Utama 2 Tarakan dan SDN 17 Tarakan, Jurnal Bidang Pendidikan Dasar 2(1A) (2018) 59-69. DOI: https://doi.org/10.21067/jbpd.v2i1a.2350

[23] M. Zuhrowati, Abdurrahman, A. Suyatna, Pengembangan Komik Sebagai Media Pembelajaran IPA pad Materi Pemanasan Glonal, Jurnal Pendidikan Fisika VI(2) (2018) 144-158.

[24] R. Anesia, B. Anggoro, I. Gunawan, Pengembangan Media Komik Berbasis Android Pada Pokok Bahasan Gerak Lurus, Indonesian Journal of Science and Mathematics Education 1(1) (2018) $53-57$.

https://ejournal.radenintan.ac.id/index.php/IJSME/i ndex

[25] M. A. Lubis, Pengembangan Bahan Ajar Komik Untuk Meningkatkan Minat Baca PPKN Siswa Min Ramba Padang Kabupaten Tapanuli Selatan, Jurnal Tarbiyah, vol. 25(2), 2018. DOI: https://doi.org/10.30829/tar.v25i2.370

[26] E. S. Syarah, E. Yetti, L. Fridani, Pengembangan Media Komik Elektronik Untuk Meningkatkan Pemahaman Konservasi Anak Usia Dini, JPUD Jurnal Pendidikan Usia Dini 12(2) (20180 231-240. DOI: https://doi.org/10.21009/jpud.122.04

[27] Y. Sari, Pengembangan Bahan Ajar Komik Ipa Dengan Penanaman Nilai Budai Pada Siswa Kelas Iv Sekolah Dasar, Jurnal Pendidikan Sekolah Dasar 3(2) (2017) $129 . \quad$ DOI: https://doi.org/10.30870/jpsd.v3i2.2134

[28] P. D. Wisada, I. K. Sudarma, S. A. I. W. I. Yuda S, Pengembangan Media Video Pembelajaran Berorientasi Pendidikan Karakter, Journal of Education Technology 3(3) (2019) 140. DOI: https://doi.org/10.23887/jet.v3i3.21735

[29] A. A. G. Agung, Buku Ajar Metodologi Penelitian Pendidikan, Yogyakarta: Aditya Media Publishing, 2014.

[30.] I. K. Suartama, Materi 4 Evaluasi dan Kriteria Kualitas Multimedia Pembelajaran Oleh: I Kadek Suartama Jurusan Teknologi Pendidikan Universitas Pendidikan Ganesha Tahun 2016, January 2016, 1-18.

[31] I. M. Tegeh, Model Penelitian Pengembangan, Yogyakarta: Graha Ilmu, 2014 
[32] S. Aeni, S. Sutrisno, Q. Mushafanah, Pengembangan Media KOPER (Kotak Permainan) pada Tema 7 Kebersamaan, Jurnal Penelitian dan Pengembangan Pendidikan, 3(3) (2019) 159. DOI: https://doi.org/10.23887/jppp.v3i3.18158

[33] A. R. Setiawan, Desain Pembelajaran untuk Membimbing Siswa Sekolah Dasar dalam Memperoleh Literasi Saintifik, April 2020. DOI: https://doi.org/10.35542/osf.io/u59f8

[34] I. K. Sudarma, I. M. Tegeh, P. D. G. Prabawa, Desain Pesan, Yogyakarta: Graha Ilmu, 2015. 